\title{
Effect of nutrient sources on bench scale vinegar production using response surface methodology ${ }^{1}$
}

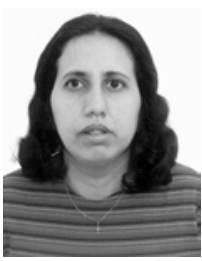

Joelma M. Ferreira², Ramdayal Swarnakar² \& Flávio L. H. da Silva²

\author{
1 Extracted from the Masters Dissertation of first author submited to UFCG \\ 2 DEQ/UFCG, Av. Aprígio Veloso, 882,CEP: 58109-970, Campina Grande, PB, Phone: (83) 310-1115. \\ E-mail: joelmamf@uol.com.br (Foto); swarna@deq.ufcg.edu.br; flhs@deq.ufcg.edu.br
}

Protocolo 142 - 5/9/2003 - Aprovado em 17/3/2004

\begin{abstract}
The present work aims to evaluate on a bench scale, the effects of nitrogen and phosphorous nutrient source concentrations in vinegar production, a process that is used by small scale industries in the State of Paraiba. The response surface methodology has been utilized for modeling and optimization of the fermentation process. Initially a $2^{3}$ complete factorial design was used, where the effects of initial concentrations of ethyl alcohol, phosphorous and nitrogen sources were observed. After this analysis the concentration range of the nutrient variables were extended and a two level plus a star configuration factorial experimental design was performed. The experimental values are well represented by the linear and quadratic model equations obtained. The optimum concentration of ethanol was $4 \%$ in which the yield and the productivity of the acetic acid were maximized to the values of $70 \%$ and $0.87 \mathrm{~g} \mathrm{~L}^{-1} \mathrm{~h}^{-1}$ respectively, for a 24 hours fermentation period. The evaluation of the quadratic models showed that the yield of vinegar is maximized from 28.1 to $51.04 \%$ and the productivity from 0.69 to $1.29 \mathrm{~g} \mathrm{~L}^{-1} \mathrm{~h}^{-1}$ when the concentration of the nitrogen nutrient in the medium is increased from 0.2 to $2.3 \mathrm{~g} \mathrm{~mL}^{-1}$. Thus, at the optimized nitrogen nutrient concentration both the yield and the productivity of the vinegar are increased by 1.85 times.
\end{abstract}

Key words: factorial design, acetic fermentation, ethanol, fermentation process

\section{Efeito das fontes de nutrientes sobre a produção de vinagre em escala de bancada, usando-se a metodologia de superfície de resposta}

\begin{abstract}
Resumo: Objetivou-se com o presente trabalho, estudar em escala de bancada, os efeitos de concentrações de fontes dos nutrientes nitrogênio e fósforo sobre a produção de vinagre de álcool, um processo muito utilizado nas indústrias de pequeno porte do Estado da Paraíba. A metodologia de superfície de resposta foi usada na modelagem e otimização de processo de fermentação acética. Inicialmente, a metodologia de planejamento fatorial completo $2^{3}$ foi utilizada, onde os efeitos das concentrações iniciais de etanol, de fontes de fósforo e de nitrogênio foram observados. Após esta análise as faixas das concentrações iniciais das variáveis de fontes de nutrientes foram ampliadas e o planejamento experimental fatorial do tipo $2^{2}$ mais configuração estrela foi realizado. Os dados experimentais foram bem representados pelas equações de modelos linear e quadrático obtidos para os dois planejamentos experimentais. As avaliações dos modelos linear e quadrático mostraram que o rendimento de vinagre foi maximizado de 28,1 a $51,4 \%$ e a produtividade de 0,69 a 1,29 $\mathrm{g} \mathrm{L}^{-1} \mathrm{~h}^{-1}$, quando a concentração da fonte do nutriente nitrogênio, no meio, foi aumentada de 0,2 a 2,3 $\mathrm{g} \mathrm{mL}^{-1}$. Portanto, na concentração otimizada da fonte de nutriente nitrogênio, o rendimento e a produtividade aumentou 1,85 vezes.
\end{abstract}

Palavras-chave: planejamento fatorial, fermentação acética, etanol, processo fermentativo

\section{INTRODUCTION}

A generic fermentative process can be considered to be consisting of two principle steps: first that of preparation of the inoculum and the second being the fermentation itself. The first step has the basic objective of microorganism preparation in appropriate condition so that the second step can be evolved adequately. Some conditions are to be established for the control of microorganism activity, so that their multiplication and successive functioning can be favored. During the growth period apart from primary nourishment the presence of some nutrients, $\mathrm{pH}$ control, and favorable temperature of the process 
are important. Thus in the case of alcohol vinegar production, addition of nutrients can improve process efficiency.

Acetic acid produced by primary microbial metabolism is denominated as acetic acid fermentation. The acetic acid fermentation is oxidation fermentation in which a dilute ethanol solution is oxidized through acetic acid bacteria (Rehm \& Reed, 1983). The acetic acid fermentation has a long history and efforts have been made to find out a better selection of acetic acid bacteria having improved process efficiencies (Fukaya et al., 1992). The Acetobacters are very productive, and untiring transformer of alcohol in to acetic acid. However, to function as such they require some special conditions of alcohol concentration, presence of nutrients, temperature, oxygenation, fermentation time and $\mathrm{pH}$ of the medium. According to Rehm \& Reed (1983), most of the acetic acid bacteria used in the vinegar industry are not derived from the pure culture. A mixed culture of Acetobacter consists of a variety of microorganisms and is considered to be more efficient. The Acetobacters are capable to ferment various sugars forming acetic acid and use this acid as a source of carbon to produce $\mathrm{CO}_{2}$ and $\mathrm{H}_{2} \mathrm{O}$. According to Cruess (1973) these bacteria are easily destroyed by heat around $65^{\circ} \mathrm{C}$ of temperature.

During understanding of the process of vinegar production man has been capable of producing various types of vinegar. The starting material utilized for the production of vinegar varies from country to country. Any fruit that contains more than $9 \%$ of sugar can be converted to vinegar. To obtain vinegar, first the alcoholic fermentation of the starting material and thereafter acetic fermentation should be done. These two fer-mentation can not continue simultaneously because of the fact that the acetic acid formed by the vinegar bacteria reduces the growth and activity of the yeast.

Fukaya et al. (1992) mention that vinegar is one of the oldest condiments. It is used to avoid the growth of fungus and has various other utilities in popular culture from health to cleaning. Fruit vinegar, as food item, is more nutritive because it contains substances like vitamins, organic acids, proteins, and amino acids originally present in the fruits. Also, the fruit wines produces vinegar that are more tasty and less bitter because they are less acidic and contain organic substances (Borzani et al., 1993). However, in case of Brazil, the ethyl alcohol is economically advantageous as it is a cheaper starting material compared to other sources. This fact motivates the substitution of fruit wines to ethanol for the production of vinegar, especially in the tropical and subtropical regions that have very developed alcohol industries.

According to Brazilian legislation vinegar or wine vinegar is a product obtained by acetic fermentation of wine and should contain minimum of $40 \mathrm{~g} \mathrm{~L}^{-1}$ of volatile acidity expressed in terms of acetic acid and being added of nutritive elements. Its alcoholic grade should not exceed by $1{ }^{\circ} \mathrm{GL}$ and must be pasteurized. Vinegar containing more than $80 \mathrm{~g} \mathrm{~L}^{-1}$ of volatile acidity is exclusively used for dilution purpose (Borzani et al., 1993).

In examining transformation processes for example fermentation and more specifically acetic fermentation, which is a multivariable system, it can be of interest to study the influence of various independent factors (input) on dependent variables (responses), like nutrient consumption, product formation and cell reproduction velocities on yield and productivity. It is easy to imagine for the inherent difficulty in studying a case like this and with this emerges one of the more common problems that a researcher can face, which is to determine a combined effect of more than one variable on the response variable of interest. One way to solve this problem is the utilization of the experimental design methodology, which has been applied with a relative success to the study of complex engineering problems. One of the advantages of experimental design consists in just grouping variables, which reduces either the number of variables being studied, or reduces the number of their levels and consequently helps to find out the correlation between them. In this manner it becomes possible to reduce considerably the number of the experimental tests that are to be made.

In factorial design, initially, it is needed to decide the specific levels that is to say the values of the factors that will be used in the experiments. In this type of design it is necessary to elaborate various experiments for all possible combinations of the levels. According to Silva (1998) the principle objective of the factorial design is to relate empirically the dependent variables with the independent variables and beside this to find out statistically the effect of each variable on the desired response.

The Response Surface Methodology (RSM) is a technique of optimization that employs the factorial design introduced by G.E.P. Box in the decade of 1950, and since then it has been utilized with great success in modeling various industrial processes (Barros Neto et al., 1995; Dey et al., 2001; Francis et al., 2003).

The factorial design of experiments and analysis of response surface has to start with fixation of number of levels for each variable and hence it is needed to perform tests with all possible combinations. It is customary to identify the higher and lower levels with the symbols (+) and (-) respectively. The design can de extended by performing experiments on axial points or in other words to complete it with more $2 \mathrm{n}$ experiments which is denominated as star configuration. The factorial design plus star configuration can also be performed with only those factors that show significant effect in initial factorial design and with experiment levels shifted by $\delta$ axially to $1-\delta,-1,+1,1+\delta$. The value of the shift $(\delta)$ is calculated by using the Eq. 1 (Box \& Wilson, 1951), where $\lambda$ is number of independent variables.

$$
\delta=\left(2^{\lambda}\right)^{1 / 4}
$$

The objective of the present work is to study optimization of acetic fermentation, a batch operation process most used in northeast region of Brazil. Initially the influence of variables: concentration of ethanol, phosphorous and nitrogen was evaluated and the response surface methodology was used. In the second stage the evaluation of the effects of nitrogen and phosphorous nutrient concentrations for vinegar production was performed. 


\section{MATERIAL AND METHODS}

Initially, for the process optimization, the $2^{3}$ factorial design under the response surface analysis was used. Thus, a more detailed information about influence of the independent variables: concentrations of alcohol, phosphorous and nitrogen source on dependent variables yield and productivity were obtained. The experiments were performed at room temperature $\left(25^{\circ} \mathrm{C}\right)$. The sugarcane husks served as inoculant for acetic bacteria and also as the reactor fillings, which is normally used in most of the vinegar producing industries of the northeast region of Brazil. The acetic fermentation reaction was performed by placing $100 \mathrm{~g}$ of the sugarcane husks in $200 \mathrm{~mL}$ reactor and adding $100 \mathrm{~mL}$ of ethanol solution that contained nitrogen and phosphorous nutrient sources of predetermined concentrations. Ammonium sulphate (Reagen) and Potassium dihydrogen phosphate (Vetec) were used as nitrogen and phosphorous nutrient sources, respectively. After 24 hours of the starting of the reaction $2 \mathrm{~mL}$ solution samples were removed for analysis. The acetic acid concentration was determined volumetrically by titration with a standardized sodium hydroxide solution $(0.1 \mathrm{M})$.

In the optimization study, the selection of level values, of each of the variables, was based on the information found in literature and are shown in Table 1 and with this a $2^{3}$ factorial design was executed by performing 11 experiments. The observed yield and productivity responses for all the possible combinations were thereby calculated.

Table 1.Variable levels for complete $2^{3}$ factorial design*

\begin{tabular}{cccc}
\hline $\begin{array}{c}\text { Variable } \\
\text { Concentration) }\end{array}$ & $\begin{array}{c}\text { Level } \\
(-1)\end{array}$ & $\begin{array}{c}\text { Central Point } \\
(0)\end{array}$ & $\begin{array}{c}\text { Level } \\
(+1)\end{array}$ \\
\hline $\mathrm{E}\left(\% \mathrm{v} \mathrm{v}^{-1}\right)$ & 3 & 6 & 9 \\
$\mathrm{P}\left(\mathrm{g} \mathrm{mL}^{-1}\right)$ & 0.01 & 0.03 & 0.05 \\
$\mathrm{~N}\left(\mathrm{~g} \mathrm{~mL}^{-1}\right)$ & 0.1 & 0.3 & 0.5 \\
\hline
\end{tabular}

* E, P and $\mathrm{N}$ - ethanol, phosphorous, and nitrogen source concentrations respectively

To obtain an estimation of variation as a function of experimental error, three repeated experiments were performed at central point (0). The experiments were realized in random order so that the possibility of non-typical error related with particular combination can be avoided.

After analyzing the results of the first design, which could not show the possible effect of phosphorous and nitrogen nutrient concentrations on the response variables, the second design was made. In the second design the concentration range of these variables were extended. This time the experimental design was of $2^{2}$ factorial + star configuration type which was performed by complementary axial points experiments along with other points not made in the first design. The variable levels of the second design are shown in the Table 2. To verify

Table 2.Variable levels for $2^{2}$ factorial design + star configuration*

\begin{tabular}{cccccc}
$\begin{array}{c}\text { Variable } \\
(\text { Concentration })\end{array}$ & $\begin{array}{c}\text { Level } \\
(1-\delta)\end{array}$ & $\begin{array}{c}\text { Level } \\
(-1)\end{array}$ & $\begin{array}{c}\text { Central Point } \\
(0)\end{array}$ & $\begin{array}{c}\text { Level } \\
(+1)\end{array}$ & $\begin{array}{c}\text { Level } \\
(1+\delta)\end{array}$ \\
\hline $\mathrm{P}\left(\mathrm{g} \mathrm{mL}^{-1}\right)$ & 0.02 & 0.05 & 0.125 & 0.2 & 0.23 \\
$\mathrm{~N}\left(\mathrm{~g} \mathrm{~mL}^{-1}\right)$ & 0.2 & 0.5 & 1.25 & 2.0 & 2.3 \\
\hline * $\mathrm{P}$ and $\mathrm{N}$ - phosphorous, and nitrogen source concentrations, respectively
\end{tabular}

the influence of each variable on the process and thus to make the possible process optimization the experimentally observed values of the variables were analyzed by using the computer program Statistica 5.0.

\section{RESULTS AND DISCUSSION}

In Table 3 the results of the first experimental design obtained experimentally for combinations of each level are presented. The order of the test performance is shown by number in parenthesis in the first column of the table. The codified linear model obtained for both the yield (\%) and the productivity $\left(\mathrm{g} \mathrm{L}^{-1} \mathrm{~h}^{-1}\right)$ of the acetic acid as a function of studied independent variable concentrations are shown by the Eq. (2) and (3) respectively. Here parameters in bold type letters represent the significant values of the model and the symbols E, $\mathrm{P}$ and $\mathrm{N}$ are coded level concentrations of ethanol, phosphorous and nitrogen respectively.

$$
\begin{array}{r}
\text { Yield }=39.68-26.36 \mathrm{E}-2.86 \mathrm{P}+0.29 \mathrm{~N}+4.00 \mathrm{EN}- \\
1.18 \mathrm{EP}+0.52 \mathrm{PN} \\
\text { Productivity }=0.77-0.11 \mathrm{E}-0.09 \mathrm{P}+0.06 \mathrm{~N}+ \\
0.11 \mathrm{EN}-0.07 \mathrm{EP}-0.01 \mathrm{PN}
\end{array}
$$

Table $3.2^{3}$ factorial experimental design and response results obtained*

\begin{tabular}{lrrrcc}
\hline Test & E & P & N & $\begin{array}{c}\text { Yield } \\
(\%)\end{array}$ & $\begin{array}{c}\text { Productivity } \\
\left(\mathrm{g} \mathrm{L}^{-1} \mathrm{~h}^{-1}\right)\end{array}$ \\
\hline $1\left(1^{\circ}\right)$ & -1 & -1 & -1 & 78.00 & 1.00 \\
$2\left(3^{\circ}\right)$ & +1 & -1 & -1 & 16.31 & 0.63 \\
$3\left(11^{\circ}\right)$ & -1 & +1 & -1 & 70.27 & 0.90 \\
$4\left(5^{\circ}\right)$ & +1 & +1 & -1 & 10.54 & 0.40 \\
$5\left(6^{\circ}\right)$ & -1 & -1 & +1 & 66.20 & 0.85 \\
$6\left(4^{\circ}\right)$ & +1 & -1 & +1 & 27.18 & 1.05 \\
$7\left(10^{\circ}\right)$ & -1 & +1 & +1 & 67.22 & 0.86 \\
$8\left(2^{\circ}\right)$ & +1 & +1 & +1 & 16.82 & 0.65 \\
$9\left(9^{\circ}\right)$ & 0 & 0 & 0 & 27.54 & 0.70 \\
$10\left(7^{\circ}\right)$ & 0 & 0 & 0 & 29.58 & 0.76 \\
$11\left(8^{\circ}\right)$ & 0 & 0 & 0 & 26.86 & 0.70 \\
\hline
\end{tabular}

The Table 4 exhibits the results of the analysis of variance (Anova) for the statistical models obtained for the yield and the productivity of the acetic acid. It can be seen that the correlation coefficient values 0.95 and 0.96 for yield and productivity respectively are significant. The calculated $\mathrm{F}$ values are higher than the tabulated $\mathrm{F}$ values at $95 \%$ level of confidence. Thus,

Table 4. Analysis of variance of the linear model for yield and productivity

\begin{tabular}{lrc} 
& Yield & Productivity \\
\hline \% Explained Variance & 90.71 & 93.11 \\
Correlation Coefficient & 0.95 & 0.96 \\
F (Calculated) & 6.51 & 9.03 \\
F Tabled for 95\% of & 6.16 & 6.16 \\
Confidence level & 1.06 & 1.46 \\
F Calculated/F Tabled & 1.06 \\
\hline
\end{tabular}


there is a good agreement between values predicted by model equations and those observed experimentally.

The response surfaces are constructed by using the linear model Eq. (2) and (3) for exhibiting the effects of the input variables on the output response variables. Figure 1 presents the effect of ethanol and phosphorous concentrations on the yield and on the productivity of acetic acid respectively while the concentration of nitrogen is maintained at central point $\left(0.3 \mathrm{gmL}^{-1}\right)$. It is verified that the yield increased with decrease in concentration of ethanol and reached a value of $70 \%$ at about $4 \%$ of ethanol concentration while phosphorous did not show any significant effect. However, it is observed that the productivity of the acetic acid was maintained to almost same value with the variation of ethanol concentration. In relation with the effect of phosphorous concentration variation both yield and productivity were not influenced visibly. The optimum productivity observed is on lower concentrations of both ethanol and phosphorous and is about $0.87 \mathrm{~g} \mathrm{~L}^{-1} \mathrm{~h}^{-1}$.
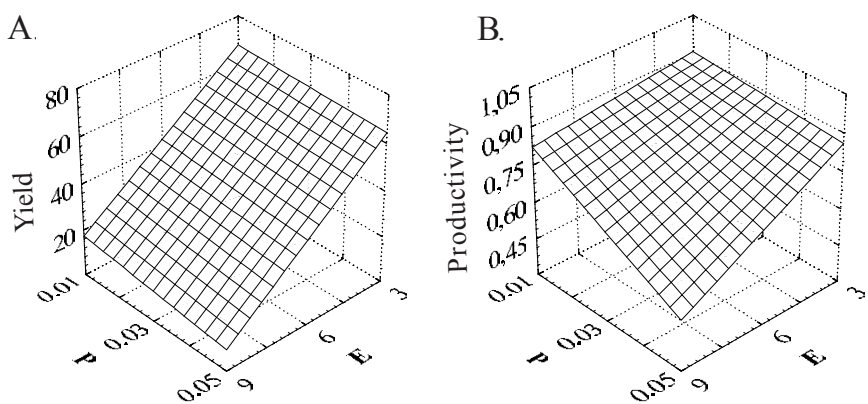

Figure 1. Response surfaces: effects of ethanol (E) and phosphorous (P) concentrations on yield (A) and productivity (B) of acetic acid

In the Figure 2 the respective response surfaces for yield and productivity are shown, where the concentrations of ethanol and nitrogen were varied and that of the phosphorous $\left(0.03 \mathrm{~g} \mathrm{~mL}^{-1}\right)$ was fixed as central point. It can be seen that for higher concentration values of ethanol and any value of nitrogen the yield of acetic acid decreases to $15 \%$. The value $0.2 \mathrm{~g} \mathrm{~L}^{-1} \mathrm{~h}^{-1}$ of the productivity of acetic acid, at $4 \%$ of ethanol and $0.2 \mathrm{~g} \mathrm{~L}^{-1}$ of nitrogen source, is observed.

The response surfaces of Figure 3 show the effect of nitrogen and phosphorous concentration variations on the yield and the productivity of acetic acid respectively, when the
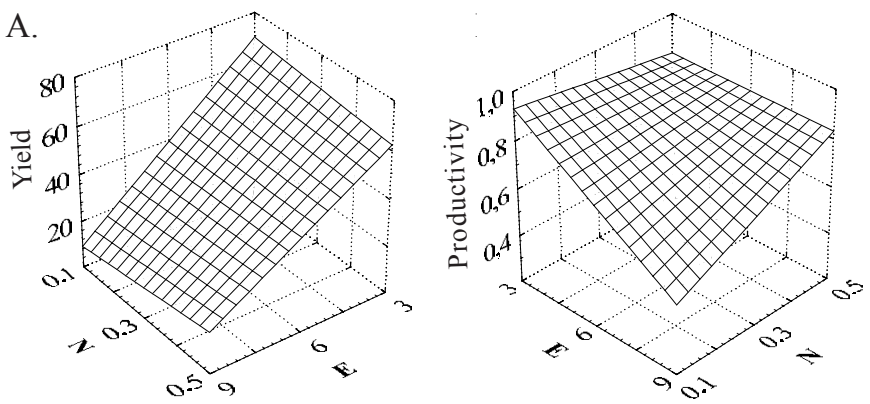

Figure 2. Response surfaces: effects of ethanol (E) and nitrogen (N) concentrations on yield (A) and productivity (B) of acetic acid concentration of ethanol was fixed at $6 \%$ as central point. It can be noted that productivity is affected to greater extent with increasing nitrogen concentration (Figure 3B) while the yield is not influenced appreciably (Figure 3A).

A
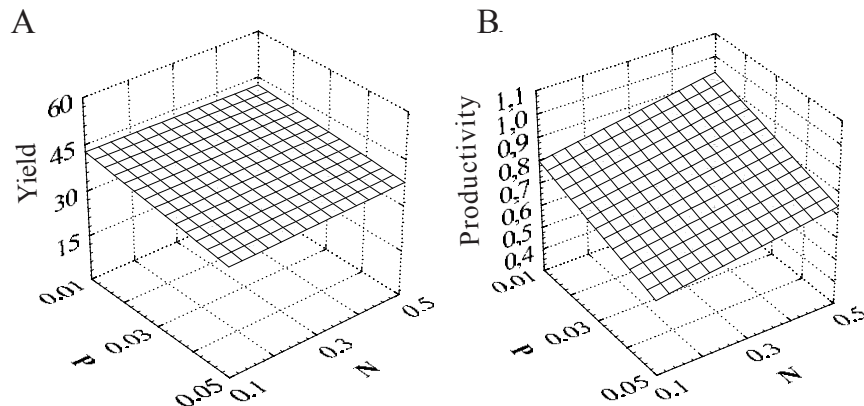

Figure 3. Response surfaces: effects of phosphorous $(\mathrm{P})$ and nitrogen $(\mathrm{N})$ concentrations the yield $(\mathrm{A})$ and productivity (B) of acetic acid

The results of the first experimental design showed that the independent variable that had relatively stronger effect on the response variable was ethanol concentration. In the second design, therefore, the ethanol concentration was fixed at $6 \%$ so that the effects of nitrogen and phosphorous nutrient sources on the response variable can be evaluated. The Table 5 presents the $2^{2}+$ star configuration factorial experimental plan and the response results obtained.

Table $5.2^{2}+$ star configuration factorial experimental design and response results obtained

\begin{tabular}{lcccc}
\hline Test & $\mathrm{P}$ & $\mathrm{N}$ & Yield $(\%)$ & Productivity $\left(\mathrm{g} \mathrm{L}^{-1} \mathrm{~h}^{-1}\right)$ \\
\hline $1\left(7^{\circ}\right)$ & -1 & -1 & 29.33 & 0.75 \\
$2\left(2^{\mathrm{o}}\right)$ & +1 & -1 & 31.96 & 0.82 \\
$3\left(4^{\circ}\right)$ & -1 & +1 & 44.33 & 1.14 \\
$4\left(8^{\circ}\right)$ & +1 & +1 & 40.29 & 1.04 \\
$5\left(9^{\circ}\right)$ & 0 & 0 & 38.93 & 0.91 \\
$6\left(3^{\circ}\right)$ & 0 & 0 & 43.35 & 1.12 \\
$7\left(1^{\circ}\right)$ & 0 & 0 & 36.72 & 0.94 \\
$8\left(5^{\circ}\right)$ & $-2^{1 / 2}$ & 0 & 40.42 & 1.04 \\
$9\left(11^{\circ}\right)$ & 0 & $2^{1 / 2}$ & 56.87 & 1.46 \\
$10\left(6^{\circ}\right)$ & $2^{1 / 2}$ & 0 & 32.98 & 0.84 \\
$11\left(10^{\circ}\right)$ & 0 & $-2^{1 / 2}$ & 27.30 & 0.70 \\
\hline
\end{tabular}

* P, N - phosphorous and nitrogen concentration coded levels respectively

The codified quadratic models are shown by the Eq. (4) and (5).

$$
\begin{gathered}
\text { Yield }=39.67+8.14 \mathrm{~N}-1.49 \mathrm{P}-2.21 \mathrm{P}^{2}+0.48 \mathrm{~N}^{2}- \\
1.67 \mathrm{PN} \\
\begin{aligned}
\text { Productivity }= & 0.99+0.21 \mathrm{~N}-0.04 \mathrm{P}-0.04 \mathrm{P}^{2}+0.03 \mathrm{~N}^{2}- \\
& 0.04 \mathrm{PN}
\end{aligned}
\end{gathered}
$$

The Table 6 presents the results of the analysis of variance (Anova) for the quadratic models obtained for the yield and the productivity of acetic acid. The correlation coefficient values are 0.93 and 0.92 for yield and productivity respectively. In relation to the $\mathrm{F}$ test it is observed that the calculated value 
of $\mathrm{F}$ is once again superior to the tabled value for $95 \%$ of confidence level, indicating that the equation is statistically significant.

Table 6. Analysis of variance of the quadratic model for yield and productivity of acetic acid

\begin{tabular}{lcc}
\hline & Yield & Productivity \\
\hline \% Explained Variance & 86.50 & 84.69 \\
Correlation Coefficient & 0.93 & 0.92 \\
F (Calculated0 & 6.40 & 5.52 \\
F (Tabulated) for 95\% of & 5.05 & 5.05 \\
Confidence level & 1.27 & 1.09 \\
F Calculated/F Tabulated & \\
\hline
\end{tabular}

The Figure 4 depicts the effects of phosphorous and nitrogen source concentrations variations on the yield and the productivity of acetic acid respectively while the concentration of ethanol is fixed at $6 \%$. It is observed that phosphorous does not have any statistically significant influence on any of the response variable. However, both the yield and the productivity increase with increase of nitrogen concentration. The evaluation of the quadratic models (Eq. 4 and 5) show that the yield of vinegar is maximized from 28.1 to $51.04 \%$ and the productivity from 0.69 to $1.29 \mathrm{~g} \mathrm{~L}^{-1} \mathrm{~h}^{-1}$ when the concentration of the nitrogen nutrient is increased from 0.2 to $2.3 \mathrm{~g} \mathrm{~mL}^{-1}$ in the medium. Thus, at the optimized nitrogen nutrient concentration both the yield and the productivity of the vinegar are increased by 1.85 times.
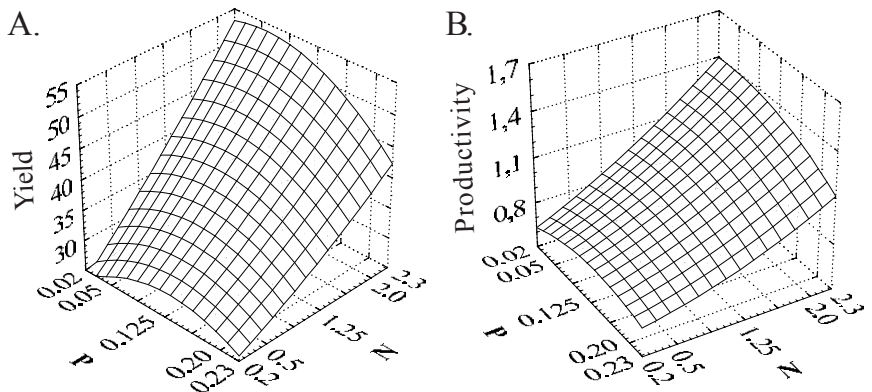

Figure 4. Response surfaces: effects of phosphorous (P) and nitrogen $(\mathrm{N})$ concentrations on yield $(\mathrm{A})$ and productivity (B) of acetic acid in the second experimental design

\section{CONCLUSIONS}

1. The response surface methodology helped to verify that the ethanol concentration is the important independent variable that influenced both the yield and the productivity of acetic acid fermentation process.

2. In the two levels plus a star configuration factorial experimental design a significant effect of nitrogen nutrient was observed.

3. The experimental values of yield and productivity of vinegar are well represented by the model equations obtained.

4. The yield and the productivity of the acetic acid were maximized to the values of $70 \%$ and $0.87 \mathrm{~g} \mathrm{~L}^{-1} \mathrm{~h}^{-1}$ respectively, for a 24-hour period fermentation, for a optimum concentration of ethanol of $4 \%$.

5. The yield of vinegar is maximized from 28.1 to $51.04 \%$ and the productivity from 0.69 to $1.29 \mathrm{~g} \mathrm{~L}^{-1} \mathrm{~h}^{-1}$.

\section{LITERATURE CITED}

Barros Neto, B.; Scarmino, J.S.; Bruns, R.E. Planejamento e otimização de experimentos, Campinas: UNICAMP, 1995. 299p.

Borzani, W.; Aquarone, E.; Lima, U.A. Alimentos e bebidas produzidos por fermentação. São Paulo: Metha Ltda, v.5, 1993.

Box, G.E.P; Wilson, K.B. On the experimental attainment of optimum condition. Journal of Royal Statistical Society, New York, v.13, p.1-45, 1951.

Cruess, W.V. Produtos industriais de frutas e hortaliças. Rio de Janeiro: Edgard Blucher LTDA, v.1, 1973. 854p.

Dey, G.; Mitra, A.; Banerjee, R.; Maiti, B.R. Enhanced production of amylase by optimization of nutritional constituents using response surface methodology. Biochemical Engineering Journal, New York, v.7, p.227-231, 2001.

Francis, F.; Sabu, A.; Nampoothiri, K.M.; Ramchandran, S.; Ghosh, S.; Szakacs, G.; Pandey, A. Use of response surface methodology for optimizing parameters of $\alpha$-amylase by Aspergillus oryzae. Biochemical Engineering Journal, New York, v.15, p.107-115, 2003.

Fukaya, M.; Park, Y.S.; Toda, K. Improvement of acetic acid fermentation by molecular breeding and process development, Journal of Applied Bacteriology, London, v.73, p.447-454, 1992.

Rehm, H.J.; Reed, G. Biomass, microorganisms for special applications, microbial products I. Energy from Renewable Resources, Weinheim, v.3, p. 388-407, 1983.

Silva, F.L.H. Modelagem, simulação e controle de fermentação alcoólica contínua extrativa. Campinas: UNICAMP, 1998.162p. Tese Doutorado 